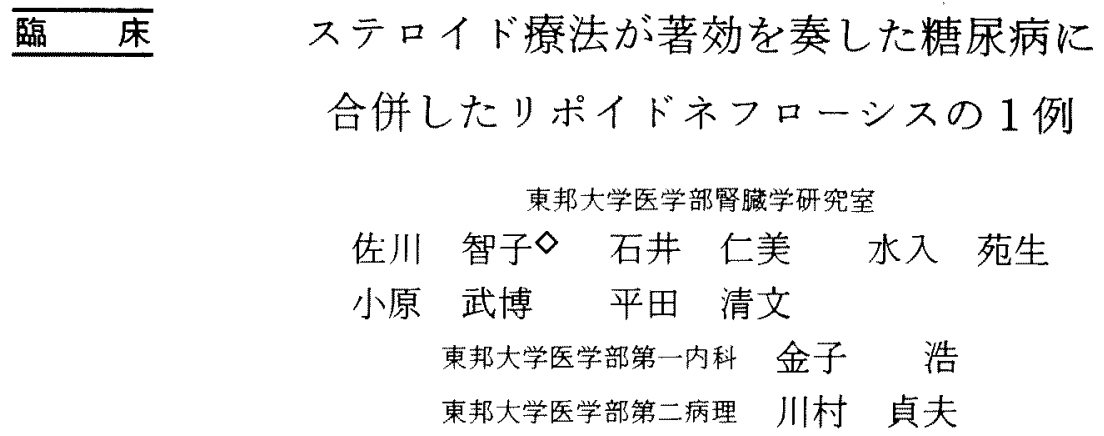

\title{
A CASE OF STEROID-SENSITIVE NEPHROTIC SYNDROME AND DIABETES MELLITUS
}

Tomoko Sagawa, MD, Hitomi Ishil, MD, SONOO Mizuiri, MD,

Takehiro OHARA, MD and Kiyofumi HiRATA, MD

The Department of Nephrology, Toho University School of Medicine, Tokyo Hiroshi KaneKo, MD

The First Department of Internal Medicine, Toho University School of Medicine, Tokyo

Sadao KawamuRa, MD

The Department of Pathology, Toho University School of Medicine, Tokyo

概要 症例は38才，女性。9 年前より糖尿病を指摘されたが，放置していた，浮腯を主訴とし て入院。入院時, 理学的に, 顏面と下肢の浮腯, 腹水を認め, 両側下肢振動覚低下, アキレス 腱反射减弱していた，検查所見では，空腹時血糖 $271 \mathrm{mg} / \mathrm{dl}$, 糖尿病性網膜症, 未梢神経障害

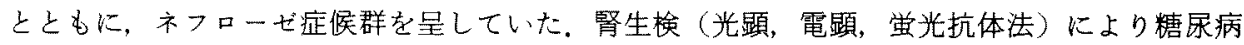

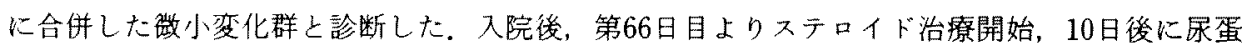

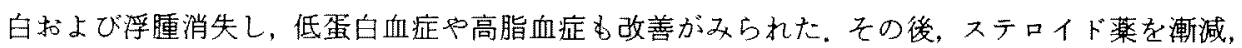
中止したが，蛋白尿出現せず，完全宽解が得られた。糖尿病にネフローゼ症候群が合併するこ とはしばしばあるが，その原因が糖尿病性腎症てなく、原発性腎疾患のリポイドネフローシス であることは極めてまれである、しかる，ステロイド療法に上り，短期間に完全寛解し充た。

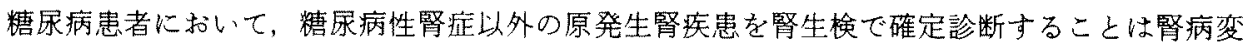
の予後と治療に扣いて極めて重要之考克られた。

はじめに

精尿病に合併するネフローゼ症候群の原因のほ とんどは，糖尿病腎症であり，原発性腎疾患であ ることは少ない，特にリポイドネフローシスであ ることは極めてまれである。今回われわれは，後 者に一致する症例を経験し，ステロイド療法によ り，完全寛解が得られたので報告する。

[昭和57年 9 月11日 第322回関東地方会推薦]
症 例

患者： 福○康○, 38才, 主婦。

主訴: 浮腫.

家族歴：母，母方の祖父，母の姉妹 5 人，計 7 人糖杘病.

既往歴：特記すべきことなし。

現病歴：昭和 48 年 6 月，第 3 子分婏時，糖尿 病指摘され，食事療法をすすめられたが，そのま ま放置していた。昭和56年夏頃より，口渴，多食， 多尿が持続していた。昭和57年 1 月 9 日朝，顔面 
と四肢の浮腫出現し, 安静にしていたが, 浮腫増 悪したため，1月11日当院へ入院した.

入院時現症：身長は $162.3 \mathrm{~cm}$, 体重 $63.5 \mathrm{~kg}$, 血圧 $120 / 80 \mathrm{mmHg}$, 脈拍 $72 /$ 分整, 意識は清明, 顔 面は浮腫状であつた。眼底は両側Scott IIaで，貧 血・黄疸ともに認めなかつた. 胸部では異常所見 なかつたが，腹部はやや膨隆し，腹水を認めた。 四肢に浮腫著明で, 両下肢の振動覚は低下し，ア キレス腱反射は減弱していた。

入院時検查成績（表 1 ）：検尿では 1 日 $13.5 \mathrm{~g}$ と高度の蛋白尿, 沈渣にて白血球 $8 \sim 10 / \mathrm{HPF}$, 硝 子円柱を認めた。血清総蛋白 $4.5 \mathrm{~g} / \mathrm{dl}$, アルブミン $2.2 \mathrm{~g} / \mathrm{dl}$, コレステロール $375 \mathrm{mg} / \mathrm{dl}$ とネフローゼ 症候群を示した。血清クレアチニン $(\mathrm{Cr})$ は 0.7

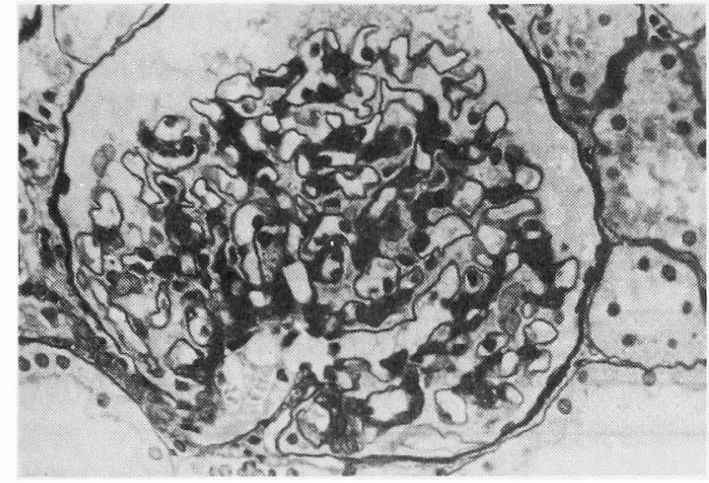

図 1 . 第 1 回腎生検光顕像 $\times 200 \mathrm{H}-\mathrm{E}$ 染色. 軽度の メサンジゥム基質の増加を認めるがminor changeで ある。 $\mathrm{mg} / \mathrm{dl}$ であつたが, クレアチニン クリアランス

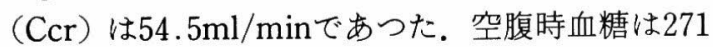
$\mathrm{mg} / \mathrm{dl}$ と高值を示した。血清では $\beta_{1} \mathrm{C} / \beta_{1} \mathrm{~A}$ グロブ リンが $49 \mathrm{mg} / \mathrm{dl}$ と低值を示した以外, 異常所見は 認めなかつた。四肢の運動神経伝導速度, 知覚神 経伝導速度は著明な低下を示した。

第 1 回腎生検所見： 昭和57年 3 月 8 日施行.

光顕H-E染色では, 6 個の糸球体は, 全て minor changeを示し，尿細管，間質には著変は認められ なかつた。軽度のメサンギウム基質の増加を認め るが，メサンギウム細胞の増殖は認められなかつ た（図 1).PAM染色では，系球体基底膜は全体 に軽度の肥厚を認めたが, spikeなどの所見は認め られなかつた(図 2). 蛍光抗体, 電顕標本には系

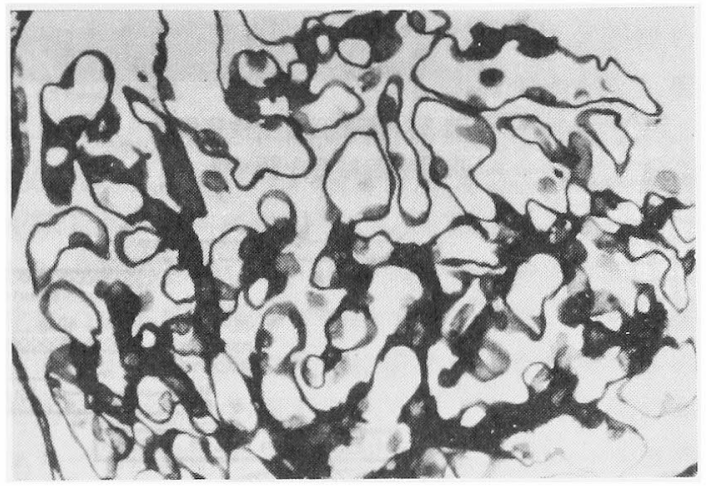

図 2 . 第 1 回腎生検光顕像 $\times 400$ PAM染色. 基底膜 は全般的に軽度の肥厚を示したが, spikeは認めない。

表 1. 入院時臨床検查成績

1. Blood examination
RBC $509 \times 10^{4} / \mathrm{mm}^{3}$
$\mathrm{Hb} \quad 15.0 \mathrm{~g} / \mathrm{dl}$
$\mathrm{Ht} \quad 45.0 \%$
$\mathrm{PIt} \quad 21.8 \times 10^{4} / \mathrm{mm}^{3}$
WBC $6800 / \mathrm{mm}^{4}$
Seg $63 \%$
E $1 \%$
B 0
Mono $4 \%$
Lym $32 \%$
ESR. $24 \mathrm{~mm}(1 \mathrm{~h})$
2. Urinalysis
Protein $13.5 \mathrm{~g} /$ day
Glucose ( H)
Aceton ( $)$
Urobilinogen Normal
Sediments
RBC $1 \sim 2 / \mathrm{HPF}$
WBC $8 \sim 10 / \mathrm{HPF}$
Epithelium 20/HPF
Hyaline Cast ( + )
Urine Culture ( $)$

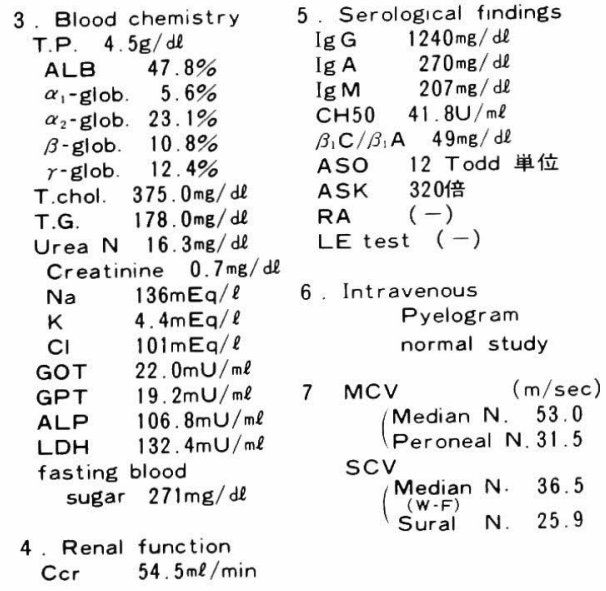




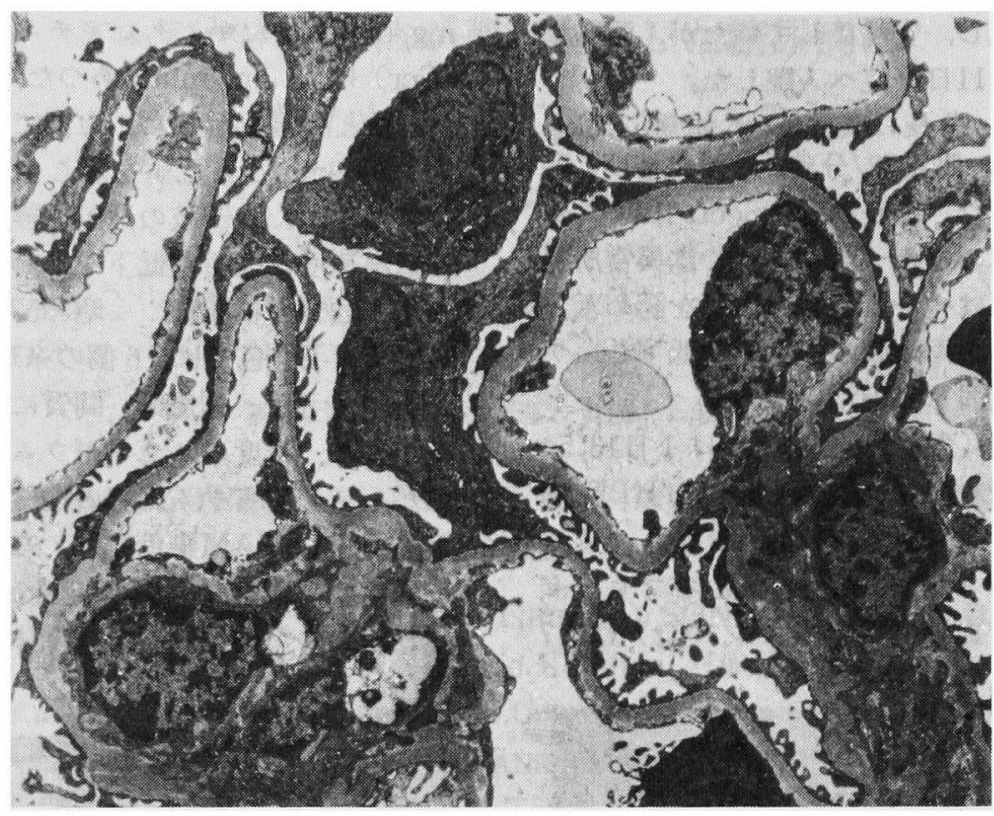

図 3. 第 2 回腎生検電䫓像 $\times 5300$. 基底膜のlamina densaの軽度肥厚と局所的な上 皮足突起融合を認める.
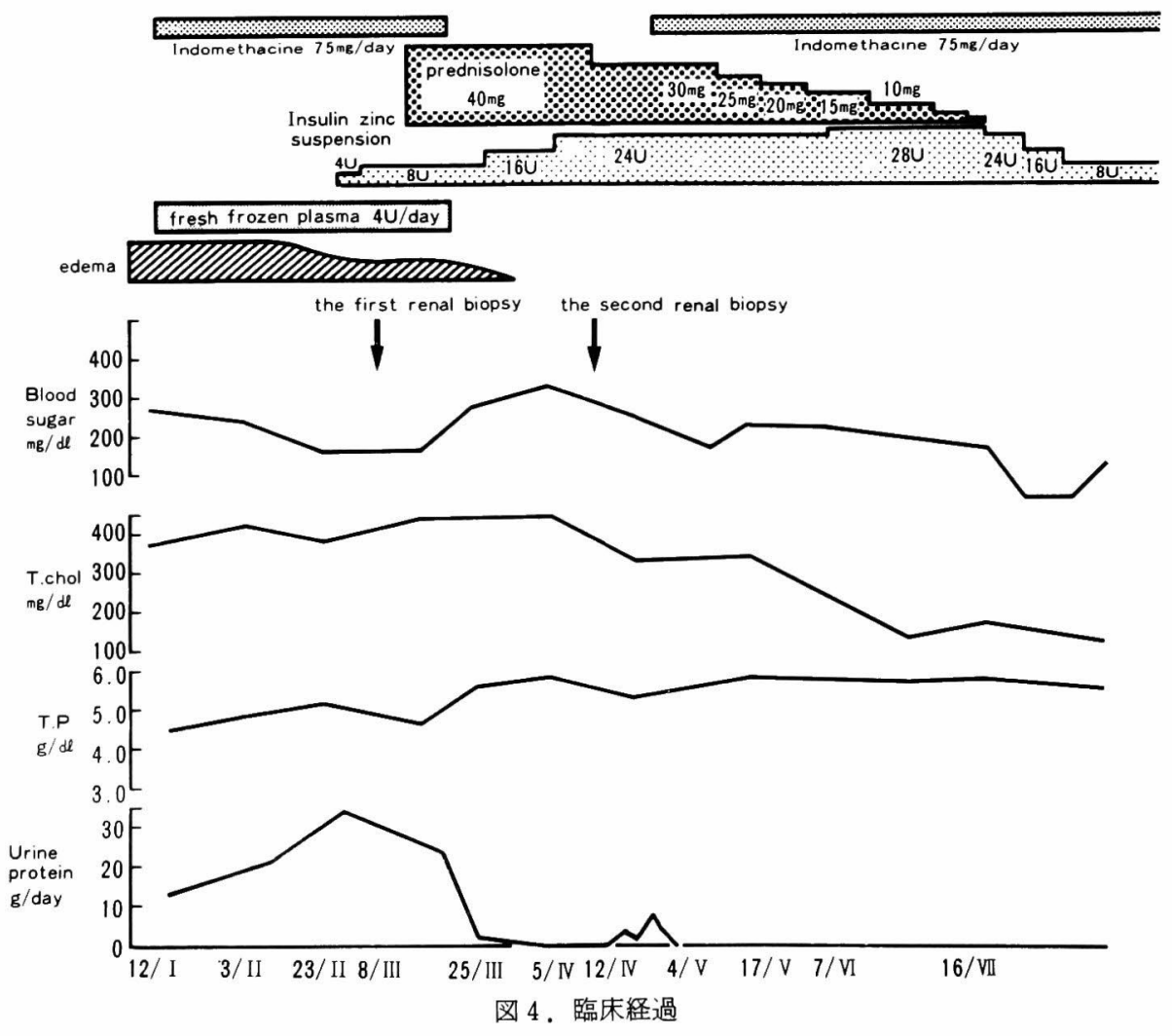
球体は認めなかつた。

第 2 回堅生検所見： 昭和57年 4 月 12 日施行.

光顕では，15個の杀球体が含まれ，第 1 回とほ ぼ同様の所見であつた。虽光抗体法では免疫グロ ブリン，補体ともに陰性であつた，電顕では，䒺 球体基底膜の lamina densaは軽度なが 5 smooth に肥厚を示し $(2400 \AA \sim 5900 \AA$ ，平均 $4000 \AA)$ ，局 所的な上皮足突起の融合と microvilliの増生拉よ び内皮下のfine granular substanceも散見された (図 3 ).

入院後経過（図 4)：楛尿病とネフローゼ症候 群の合併例と診断し, $1440 \mathrm{Kcal} の$ 食事寮法, イン スリン凍結ヒト血浆，利尿薬，インドメサシン 等で, 治療するも浮睡の軽減を認めただけで, 蛋 白尿，低蛋白血症は改善しなかつた。 そこで第 1 回腎生検の所見に基づき，3月17日よりプレドニ ソロン $40 \mathrm{mg} /$ 日の投与を開始した。開始後 10 日目 に蛋白尿消失した。年の後, 徐々に低蛋白血症, 高コレステロール血症も改善が見られ, 浮腫も完 全に消失した。第 2 回腎生検施行頃より再び3 -5 g/日の蛋白尿の出現をみたのでインドメサシン $75 \mathrm{mg} /$ 日を併用したところ，蛋白尿は再び消失し た。その後プレドニソロンを漸减，中止したが， 蛋白尿出現せず，完全寛解が得られた。な拉，経 過中, プレドーソロン投与のため, 空腹時血糖は 増悪したが,インスリンの増量により,コントロー ルできた。糖尿病絧膜症，末梢神経障害について は増悪を認めなかつた。

\section{考案}

ネフローゼ症候群は，糖尿病腎症にしばしば認 められる合併症であり, Gellmanら”の報告による と糖疗病腎症の $26 \%$ 認められたとしている。

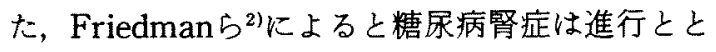
もに尿蛋白量が増加し，ネフローゼ症候群を呈す る注よ゙の高度の蛋白尿となる。そして腎機能が低 下し腎不全へ移行するとしている。一般に糖尿病 腎症によるネフローゼ症候群では，高血王，糖尿 病性網膜症，腎機能低下などをすでに合併してい る場合が多い。この時期の腎生検所見は，びまん 性糸球体硬化症を呈するのが普通である1314)。一 方，リポイドネフローシスは，1913年, Munk ${ }^{5}$ に よつて提唱された純粋な（原発性の）代表的ネフ ローゼ症候群であるがその患者の殆どすべてに高
血圧, 心肥大, 高窒素血症は認められないと述べ

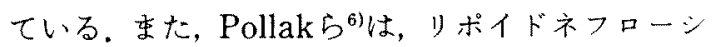
スの診断は臨床的执よび病理学的所見の両者から 決定されるべきもので，一般にステロイド薬が極 めて有効で予後良好なネフローゼ症候群であると している。

本例は，糖尿病歴が 9 年と比較的長期にわたる も高血王，血清クレアチニンの上昇を認めなから たが，入院時クレアチニンクリアランスが54.5 $\mathrm{ml} / \mathrm{min}$ 軽度低下していたのは, 高度のネフロー ゼ症状として全身浮腫, 尿量減少があつたためで， 利尿が開始するとともにクレアチニンクリアラ ンスは正常域に回復した。充た, $\beta_{1} \mathrm{C} / \beta_{1} \mathrm{~A}$ 值の軽度 低下は，総補体值が正常であつたことと持続性で なかつたことより，有意でないと考えられた。

本症例の腎生検所見は, 光顕上, minor glomerular abnomalitiesの所見で, 電顕により基底膜の 厚さは $2400 \AA \sim 5900 \AA$, 平均 $4000 \AA$ であつた。坂 ロらクによると正常値は報告者により異なるが， $3000 \AA$ が上限であり, 糖疗病患者では一般に高值 を示し，少数例に平均值が 1 を越克るものもみら れたと報告している。本症例のメサンギウムの变 化については，極めて軽数であり，坂口らの糖尿 病前期や疑糖疗病の段階に認められた程度のもの であつた，以上の病理学的所見より，本症例のネ フローゼ症候群の原因はりポイドネフローシスの 合併によるものと診断した。ささらに臨床的にステ ロイド薬が著効を奏したことは，これを支持して いる。糖疗病患者に特発性ネフローゼ症候群を合 併した報告例は少ない. 小児では, Urizerら ${ }^{8)}$ が 5 例報告し，らち4例はステロイド薬投与により完 全寛解を得ている５例の腎生検所見は, normal or minimal focal glomeulitisであり，基底膜の厚

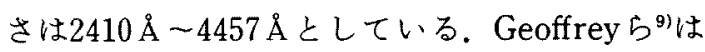
腎生検を施行していないが，8才の糖尿病患者に ネフローゼ症候群を合併し，ステロイド薬・免度 抑制剂を使用して効果があつた 1 例を報告してい る。一方，成人の糖尿病患者儿合併する特発性帟 フローゼ症候群の原因が膜性腎症によるといら報 告例は，表 2 に示すよ5に小林ら ${ }^{10)}$ の 3 例， Rao $ら^{11)}$ の 3 例, Warm ${ }^{12)}$ の 1 例, 計 7 例にみられ た、そのらち、Warmらの症例は免疫抑制剤が投与 されたが無効であつたと報告されている，成人の 
表 2 . 成人の糖疗病患者に合併した特発性ネフローゼ症候群の原因が原発性腎疾患に よるといら報告例

\begin{tabular}{|c|c|c|c|c|c|c|c|c|}
\hline Authors & Age & Sex & $\begin{array}{l}\text { Duration } \\
\text { of DM } \\
\text { years }\end{array}$ & $\begin{array}{c}\text { Urine } \\
\text { Protein } \\
\text { g/day }\end{array}$ & $\begin{array}{c}\text { Serum } \\
\text { albumin } \\
\mathbb{B} / d t\end{array}$ & $\begin{array}{c}\text { Serum } \\
\text { cholester o } \\
\text { ag/de }\end{array}$ & $\begin{array}{l}\text { Pathological } \\
\text { findings }\end{array}$ & therapy \\
\hline \multirow{3}{*}{$\begin{array}{c}\text { Kazuo Kobayashi } \\
(1981)\end{array}$} & 67 & $\hat{b}$ & 7 & 10.0 & 2.0 & 546 & $\begin{array}{c}\text { membranous } \\
G N\end{array}$ & \\
\hline & 56 & 우 & 8 & 7.1 & 2.4 & 550 & $\begin{array}{c}\text { membranous } \\
G N\end{array}$ & \\
\hline & 42 & $\delta$ & 4 & 5.8 & 2.1 & 460 & $\begin{array}{c}\text { membranous } \\
G N\end{array}$ & \\
\hline \multirow{3}{*}{$\begin{array}{l}\text { K.Venkateswara } \\
\begin{array}{l}\text { RaO } \\
(1980)\end{array}\end{array}$} & 66 & 孚 & 20 & $3 \sim 8$ & 2.1 & 310 & $\begin{array}{c}\text { membranous } \\
\text { GN }\end{array}$ & \\
\hline & 42 & 需 & 14 & $8 \sim 9$ & 1.7 & 425 & $\begin{array}{c}\text { membranous } \\
\text { GN }\end{array}$ & \\
\hline & 32 & $\hat{b}$ & 15 & $27 \sim 35$ & 2.2 & 404 & $\begin{array}{c}\text { membranous } \\
G N\end{array}$ & \\
\hline $\begin{array}{c}\text { A. Brulles } \\
(1977)\end{array}$ & 38 & $\hat{\delta}$ & 15 & 7.05 & 1.2 & 440 & lipoid nephnosis & $\begin{array}{l}\text { Predonine } 1.5 \mathrm{ng} / \mathrm{kg} \\
\text { Complete remission }\end{array}$ \\
\hline $\begin{array}{c}\text { Peter GWarms } \\
(1973)\end{array}$ & 56 & 오 & 19 & $\begin{array}{r}6.9- \\
11.3\end{array}$ & 0.59 & & $\begin{array}{c}\text { membranous } \\
G N\end{array}$ & $\begin{array}{l}\text { Cyclophosphanide } \\
2 \text { wg/kg/day } \\
\text { no change }\end{array}$ \\
\hline
\end{tabular}

桾疗病患者に特ける特発性ネフローゼ症候群がリ ポイドネフローシスによるといら報告は，われわ れの調查した限りではBrullesら ${ }^{13)}$ の 1 例のみで あり，わが国では本例が初めての症例と考光られ た. Brullesらの症例本例之同様，ステロイド治 療が著効を奏し，完全寬解を得ている。糖氺病に ネフローゼ症候群が合併した場合，そのほとんど が糖疗病性腎症によるものとされ，腎生検が夷施 されないことす両病变(糖㽷病、リポイドネフロー シス）の合併が少ない理由の一つであると考えら れた。

糖尿病患者に扔いて合併する原発性堅疾患を腎 生検によつて確定診断することは，予後の判定や 治療法の巽択上, 極めて重要なことが示唆された。

\section{結語}

われわれは，結疗病患者でリポイドネフローシ スを合併し、ステロイド療法により完全寛解が得 られた 1 症例を経験したので報告した。本症例の ような成人の糖尿病に拈いてりポイドネフローシ スを合併した症例は本邦第1例であり，世界中で 子調べ得た限りでは第 2 例目である。

\section{文献}

1) Gellman DD, et al: Diabetic nephropathy. A clinical and pathologic study based on renal biopsies. Medicine 38: 321, 1959.

2) Friedman EA, Beyer MM: Uremia in Diabetics: The Prognosis Improves. Klin Wochenschr $58: 1023,1980$.
3) Brun C, et al: Diabetic Nephropathy : Kidney biopsy and renal function tests. Amer J Med $15: 187,1953$.

4) Taft HP, et al : A biopsy study of the kidney in diabetes mellitus. Australasian Ann Med 3: 189, 1954.

5) Munk F: Klinische Diagnostik der Degerativen Nierenkrankungen. Z Klin Med 78: 1, 1913.

6) Pollak VE, et al: Natural history lipoid nephrosis and membranous glomerulonephritis. Ann Intern Med $69: 1171,1968$.

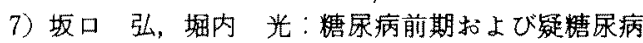
に抢ける手球体の電影像。糖疗病 $8: 145 ， 1965$.

8) Urizer RE, et al: The nephrotic syndrome in children with diabetes mellitus of recent onset. New Engl J Med 281: 173, 1969.

9) Geoffrey C, et al: Simultaneous onset of diabetes mellitus and the nephrotic syndrome. Canad MAJ 85 : 80, 1961.

10) Kobayashi $K$, et al: Idiopathic membranous glomerulonephritis associated with diabetes mellitus. Nephron 28: 163, 1981.

11) Rao KV and Crosson JT: Idiopathic mem. branous glomerulonephritis in diabetic patients. Arch Intern Med $140: 624,1980$.

12) Warms PC, et al: Idiopathic membranous glomerulonephritis occuring with diabetes mellitus. Arch Intern Med 132: 735, 1973.

13) Albert Brulles, et al: Nephrotic syndrome with minimal glomerular lesion in adult diabetic patient. Arch Pathol Lab Med 101 : 270, 1977. 